\title{
Electroanalytical Determination of the Anti- inflammatory Drug Tenoxicam in Pharmaceutical Dosage Forms
}

\author{
Anti-enflamatuvar Illaç Tenoksikamın Farmasötik Dozaj Formlarından \\ Elektroanalitik Miktar Tayini
}

\author{
(D) Fatma AĞIN*, (D) Sena ATAL \\ Karadeniz Technical University, Faculty of Pharmacy, Department of Analytical Chemistry, Trabzon, Turkey
}

\begin{abstract}
Objectives: The electro-oxidation behavior of the non-steroidal anti-inflammatory drug tenoxicam (TX) was studied on multiwalled carbon nanotube (MWCNT)-modified glassy carbon electrode (GCE) by cyclic voltammetry, differential pulse voltammetry (DPV), and square wave voltammetry (SWV).

Materials and Methods: The GCE was modified with MWCNT for sensitive determination of TX by voltammetric methods.

Results: The current peaks for TX occurred at around $0.520 \mathrm{~V}$ for DPV and $0.570 \mathrm{~V}$ for SWV when the potential was scanned in the positive direction. The oxidation process of TX showed irreversible and diffusion-controlled behavior. The linear responses were obtained in the range from $2 \times 10^{-7}$ to $1 \times 10^{-5} \mathrm{M}$ with the limit of detection (LOD) $1.43 \times 10^{-9}$ for DPV and from $8 \times 10^{-9}$ to $8 \times 10^{-6}$ with the LOD $9.97 \times 10^{-10}$ for SWV in $1 \mathrm{M}$ acetate buffer solution at $\mathrm{pH} 5.5$.

Conclusion: Fully validated DPV and SWV were successfully applied for the determination of TX from pharmaceutical dosage form and yielded satisfying results.
\end{abstract}

Key words: Glassy carbon electrode, multiwalled carbon nanotubes, tenoxicam, voltammetry

ÖZ

Amaç: Non-steroidal antienflamatuvar ilaç etken maddesi tenoksikamın (TX) elektro-oksidasyon davranışı çok duvarlı karbon nanotüple (MWCNT) modifiye edilmiş camsı karbon elektrot (GCE) ile dönüșümlü voltametri, diferansiyel puls voltametri (DPV) ve kare dalga voltametri (SWV) ile çalışıımıştır.

Gereç ve Yöntemler: GCE, TX'in voltametrik metodlarla hassas tayini için MWCNT ile modifiye edilmiştir.

Bulgular: Potansiyel pozitif yönde tarandığında TX'in pik akımı $0.520 \mathrm{~V}$ civarında DPV ile, $0.570 \mathrm{~V}$ civarında SWV ile olușmuștur. TX'in oksidasyon prosesi tersinmez ve diffüzyon kontrollü davranış göstermiștir. DPV ve SWV için doğrusal cevaplar sırasıyla $2 \times 10^{-7}-1 \times 10^{-5} \mathrm{M}, 1.43 \times 10^{-9} \mathrm{M}$ yakalama alt sınırı (LOD) ile, $8 \times 10^{-9}-8 \times 10^{-6} \mathrm{M}, 9.97 \times 10^{-10} \mathrm{M}$ LOD ile $1 \mathrm{M}$ asetat tamponu pH 5.5 içinde elde edilmiştir.

Sonuç: Tamamen valide edilmiş DPV ve SWV başarılı bir şekilde TX'in farmasötik dozaj formundan miktar tayini için uygulanmış ve memnun edici sonuçlar elde edilmiştir.

Anahtar kelimeler: Camsı karbon elektrot, çok duvarlı karbon nanotüp, tenoksikam, voltametri 


\section{INTRODUCTION}

Tenoxicam (TX) (Figure 1) is a non-steroidal anti-inflammatory drug and shows analgesic, anti-inflammatory, and antirheumatic properties. TX, a member of the oxicams class, is widely used to relieve swelling, inflammation, stiffness, and pain associated with osteoarthritis, rheumatoid arthritis, arthrosis, ankylosing spondylitis, arthritic diseases such as tendinitis, bursitis, shoulder or hip periarthritis (shoulder-hand syndrome), sprains and injuries, and acute gout. TX inhibits prostaglandin biosynthesis both in vitro and in vivo. It shows a strong inhibitory effect in vitro on human metalloproteinase (stromelysin and collagenase) enzymes that stimulate cartilage destruction.?<smiles>CN1C(C(=O)Nc2ccccn2)=C(O)C2=C(CC=[SH]2)S1(=O)=O</smiles>

Figure 1. Chemical structure of TX

TX: Tenoxicam

In the literature, high performance liquid chromatography, ${ }^{2-7}$ thin layer chromatography, ${ }^{8}$ flow injection spectrophotometric analysis, ${ }^{9-11}$ and spectrophotometric and spectrofluorimetric methods ${ }^{12-15}$ are reported as methods for the determination of TX in pharmaceuticals and biological samples. These methods require mostly time-consuming sample preparation procedures such as extraction and the costly instrumentation makes their usage inconvenient. Electrochemical methods are user friendly, no pretreatment is required for them, and they use low-cost instrumentation and minimum amount of organic solvent compared to the reported analytical methods. Additionally, electrochemical methods supply high sensitivity, precision, accuracy, and wider linear dynamic range. ${ }^{16,17}$

TX was determined using a differential pulse polarographic method in pharmaceuticals and blood, with a static mercury drop electrode..$^{18}$ El-Maali et al..$^{19}$ investigated the electro-reduction behavior of TX and piroxicam at the static mercury drop electrode. The electro-reduction of TX was also investigated using a hanging mercury drop electrode..$^{20}$

In recent years, working electrodes were modified with carbon nanotubes (CNTs) for electrochemical and bio-electrochemical studies. ${ }^{21,22}$ CNTs can be used as electrode materials with useful properties; they show excellent high chemical stability, high mechanical strength, and a wide range of electrical conductivity. CNTs supply a modifier to promote electron transfer reactions between many biologically important species and the surface of the electrode. CNT-modified electrodes have been reported to have excellent electroanalytical properties such as low background current, wide potential window, high sensitivities, and low detection limits. ${ }^{23}$ The excellent properties of CNTs make them extremely popular for obtaining chemical sensors and they are used for electrochemical detection. ${ }^{24}$

The aim of the present study was to develop a multiwalled (MW)CNT-modified glassy carbon electrode (GCE) for electroanalytical determination of TX and to investigate the electro-oxidative behavior of TX with voltammetric methods. The obtained MWCNT-modified GCE and fully validated voltammetric methods indicated a low detection limit, high selectivity and sensitivity, and good recovery results in the electroanalytical determination of TX.

\section{EXPERIMENTAL}

\section{Instrumentation}

All experiments were carried out using a three-electrode electrochemical cell with a GCE (Bioanalytical Systems, $\phi: 3$ $\mathrm{mm}$ diameter) as the working electrode, a platinum wire as the counter electrode (Bioanalytical Systems), and a $\mathrm{Ag} / \mathrm{AgCl}$ electrode (Bioanalytical Systems, 3.0 M KCl) as the reference electrode. All voltammetric measurements were performed using an Autolab Pgstat128n potentiostat/galvanostat with Nova 10.0 software (Metrohm-Autolab, The Netherlands). The $\mathrm{pH}$ measurements were carried out using a Hanna HI2211 $\mathrm{pH}$ meter (Romania) with an accuracy of $\pm 0.05 \mathrm{pH}$ at room temperature. All of the electrochemical measurements were performed at room temperature $\left(25 \pm 1^{\circ} \mathrm{C}\right)$.

\section{Reagents}

TX was supplied by Deva (Turkey) and its pharmaceutical dosage form (Tilcotil ${ }^{\circledast}$ tablets, $20 \mathrm{mg}$ of TX per tablet) was purchased from a pharmacy and was used without further purification. TX stock solutions $\left(1 \times 10^{-3} \mathrm{M}\right)$ were prepared in methanol and stored at $+4^{\circ} \mathrm{C}$ away from light. TX working solutions for the voltammetric investigation were prepared by direct dilution of the stock solution with the selected supporting electrolyte containing a constant amount of methanol ( $20 \% \mathrm{~V} / \mathrm{V})$. MWCNT were purchased from Nano-Lab (USA) with 95\% purity, 1-5 $\mu \mathrm{m}$ lengths and $30 \pm 10 \mathrm{~nm}$ diameter. $\mathrm{N}, \mathrm{N}$-Dimethylformamide (DMF) was from Fluka (Switzerland).

Britton-Robinson buffer solutions $(0.04 \mathrm{M})$ were prepared at $\mathrm{pH}$ 3.0-8.0 from 0.04 $\mathrm{M} \mathrm{CH}_{3} \mathrm{COOH}$ (Merck, Germany), $0.04 \mathrm{M}$ $\mathrm{H}_{3} \mathrm{BO}_{3}$ (Aldrich, USA), and $0.04 \mathrm{M} \mathrm{H}_{3} \mathrm{PO}_{4}$ (Merck, Germany). Acetate buffer solutions (1 M) at $\mathrm{pH} 3.5,4.5$, and 5.5 were prepared from $1 \mathrm{M} \mathrm{CH}_{3} \mathrm{COOH}$ (Merck, Germany). Phosphate buffer solutions $\left(0.1 \mathrm{M}\right.$ ) were prepared from $\mathrm{H}_{3} \mathrm{PO}_{4}$ (Merck, Germany) for $\mathrm{pH}$ 2.0-4.0 and $\mathrm{Na}_{2} \mathrm{HPO}_{4}$ (Aldrich, USA) and $\mathrm{NaH}_{2} \mathrm{PO}_{4}$ (Merck, Germany) for $\mathrm{pH}$ 5.0-8.0. The $\mathrm{pH}$ values were adjusted with $5 \mathrm{M} \mathrm{NaOH}$ (Aldrich, USA) solution.

Sartorius Arium proUV nanopure water (resistivity $\geq 18 \mathrm{M} \Omega$ $\mathrm{cm}$ ) and analytical reagents were used for the preparation of solutions.

\section{Preparation of the MWCNT-modified GCE}

First $0.2 \%$ and $0.5 \%$ ( $\mathrm{mg} \mathrm{mL}^{-1}$ ) MWCNT dispersions in DMF were sonicated for $4 \mathrm{~h}$ to obtain a homogeneous mixture. The GCE was polished with aqueous slurry of alumina powder ( $\phi: 0.01$ 
$\mu \mathrm{M}$ ) on a polishing pad (Bioanalytical Systems polishing pad) and then rinsed with nanopure water before coating it. Four different suspensions of MWCNT in DMF 2.5 and $5 \mu \mathrm{L} / 0.2 \%$ and 1 and $5 \mu \mathrm{L} / 0.5 \%$ were dropped on the surface of the GCE to select suspension of MWCNT according to the optimum peak current obtained for TX. The selected dispersion of MWCNT in DMF for voltammetric determination of TX was dropped on the surface of the GCE. The resulting modified electrode was named an MWCNT-modified GCE. The MWCNT-modified GCE electrode dried overnight at room temperature. After each measurement, the electrode surface was cleaned using cyclic voltammetry $(\mathrm{CV})$ in the potential range between $-0.4 \mathrm{~V}$ and +1.0 $\mathrm{V}$ (3 cyclic) in buffer solution.

\section{Pharmaceutical assay}

Ten Tilcotil ${ }^{\circledR}$ tablets (each tablet includes $20 \mathrm{mg}$ of TX) were first weighed and then powdered in a mortar. The needed amount of powder equivalent to $1 \times 10^{-3} \mathrm{M}$ of TX was diluted to $25 \mathrm{~mL}$ with methanol and sonicated for $10 \mathrm{~min}$. The analyzed solutions were prepared by taking aliquots of the clear supernatant liquor and diluting with the selected supporting electrolyte. TX working solutions for voltammetric inquiries were prepared by direct dilution of the stock solution with $1 \mathrm{M}$ acetate buffer solution at $\mathrm{pH} 5.5$ containing a constant amount of methanol ( $20 \% \mathrm{~V} / \mathrm{V})$.

\section{RESULTS AND DISCUSSION}

The fabrication of the MWCNT-modified GCE was optimized to obtain the best MWCNT suspension for TX oxidation. The effect of the volume of MWCNT in DMF suspension on the peak current was investigated at four different loadings of MWCNT (2.5 and $5 \mu \mathrm{L} / 0.2 \%, 1$ and $5 \mu \mathrm{L} / 0.5 \%$ ) on the surface of the GCE. The coated electrodes with $2.5 \mu \mathrm{L}$ and $5 \mu \mathrm{L}$ for $0.2 \%$ and $1 \mu \mathrm{L}$ and $5 \mu \mathrm{L}$ for $0.5 \%$ of MWCNT suspension were used to determine $4 \times 10^{-5} \mathrm{M}$ TX by CV, differential pulse voltammetry (DPV), and square wave voltammetry (SWV). As shown in Figure 2, in DP voltammograms obtained from TX the peak current reaches its maximum value $(2.47 \mu \mathrm{A})$ when the amount of MWCNT suspension ( $0.2 \%$ ) is $2.5 \mu \mathrm{L}$. Thus, $2.5 \mu \mathrm{L}$ for $0.2 \%$ MWCNT suspension was chosen to modify the GCE and this electrode was used for all electrochemical studies. Moreover, Figure 2 shows the response of TX obtained on a bare GCE $(0.040 \mu \mathrm{A})$. The peak current of TX on the MWCNT-modified GCE (a) increased about 60-fold compared to the peak current of TX on the bare GCE (e).

\section{Voltammetric behavior of TX at the MWCNT-modified GCE}

Voltammetric responses of TX were checked out in detail by CV, DPV, and SWV using the MWCNT-modified GCE over the $\mathrm{pH}$ range of 2.0-8.0 in different buffer solutions. The cyclic voltammograms of $1 \times 10^{-5} \mathrm{M}$ TX solution exhibited an irreversible electrochemical oxidation process on the MWCNT-modified GCE in all working solutions (Figure 3). The CV scan was carried out from $-0.40 \mathrm{~V}$ to $1.0 \mathrm{~V}$ in the positive direction and an anodic response of TX was observed at about $+0.55 \mathrm{~V}$ at a scan rate of $100 \mathrm{mV} \mathrm{s}^{-1}$.
The influence of $\mathrm{pH}$ on the peak current and potential was examined from $\mathrm{pH} 2.0$ to 8.0 using CV, DPV, and SWV. The results acquired from CV, DPV and SWV showed similarity. Therefore, only DPV results for the main oxidation step are shown as $E_{\mathrm{p}}-\mathrm{pH}$ and $I_{\mathrm{p}}-\mathrm{pH}$ plots in Figure 4. The peak potentials of the responses were shifted to more negative potentials by increased $\mathrm{pH}$. This is based on the oxidation of conjugate base at less positive potentials compared to the corresponding acid form. The TX oxidation peak that corresponds to the electroactive group in acid-base equilibrium with a $\mathrm{pK}_{\mathrm{a}}$ of about $5.5^{25}$ indicates $\mathrm{pH}$ dependence. Above $\mathrm{pH}$ 5.5, the peak potential is $\mathrm{pH}$ independent (Figure 4a). The linear relationship between

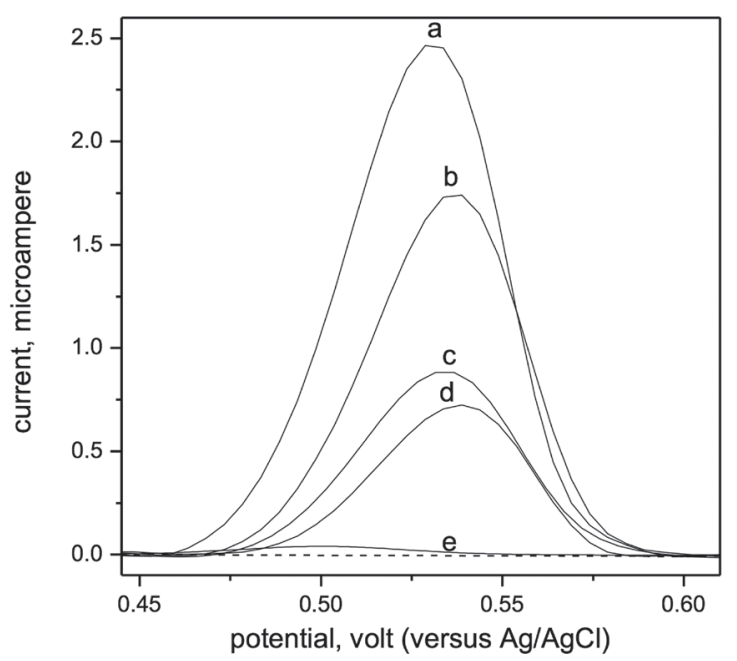

Figure 2. Differential pulse voltammograms $4 \times 10^{-5} \mathrm{M}$ of $\mathrm{TX}$ in $0.04 \mathrm{M}$ Britton-Robinson buffer at pH 5.0 a) $0.2 \% 2.5 \mu \mathrm{L}$, b) $0.2 \% 5 \mu \mathrm{L}, \mathrm{c}) 0.5 \% 1$ $\mu \mathrm{L}$, d) $0.5 \% 2.5 \mu \mathrm{L}$ of MWCNT-modified GCE, e) bare GCE. Dash line; $0.04 \mathrm{M}$ Britton-Robinson buffer solution on $0.2 \% 2.5 \mu \mathrm{L}$ of MWCNT-modified GCE TX: Tenoxicam, MWCNT: Multiwalled carbon nanotube, GCE: Glassy carbon electrode

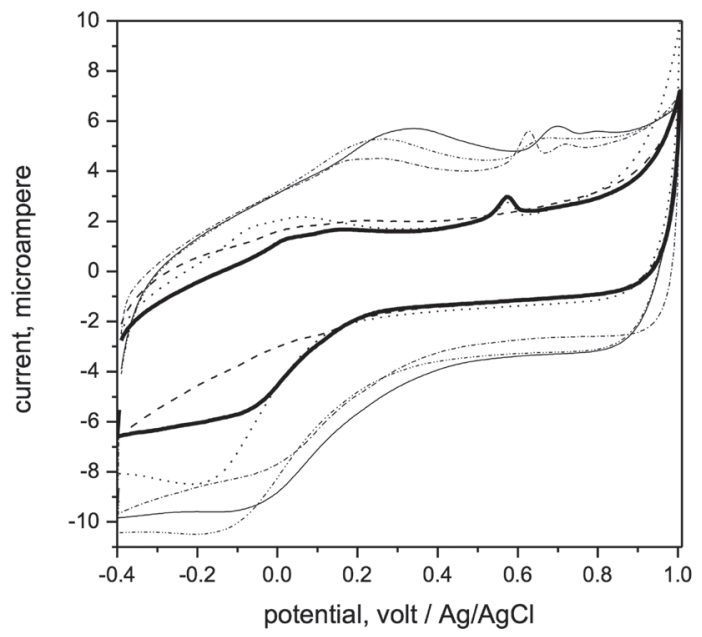

Figure 3. Cyclic voltammograms of $1.0 \times 10^{-5} \mathrm{M}$ TX in $1 \mathrm{M}$ acetate buffer at pH 3.5 (-.-.), pH 5.5 (_), 0.04 M Britton-Robinson buffer pH 3.0 (_), pH 4.0 $(-. .-), 0.1 \mathrm{M}$ phosphate buffer at pH 7.0 (....) with MWCNT-modified GCE. $1 \mathrm{M}$ acetate buffer at $\mathrm{pH} 5.5(---)$; scan rate $100 \mathrm{mV} \mathrm{s}^{-1}$

TX: Tenoxicam, MWCNT: Multiwalled carbon nanotube, GCE: Glassy carbon electrode 
$E_{\mathrm{p}}$ and $\mathrm{pH}$ can be clarified according to the following equation between 2.0 and 5.5 in all supporting electrolytes: $E_{\mathrm{p}}(\mathrm{mV})=$ $-24.7 \mathrm{pH}+654.2(\mathrm{r}=0.9987)$. The slope value (-24.7) was about half of $-59.0 \mathrm{mV} / \mathrm{pH}$, and so it was inferred that the number of protons is half of the number of electrons transferred in the TX reaction. This can be attributed to the oxidation of the amide group in the structure of TX.

The impact of $\mathrm{pH}$ on the TX peak current on the MWCNT-modified GCE indicated that the peak current of TX was maximum in 1 $\mathrm{M}$ acetate buffer at $\mathrm{pH} 5.5$ (Figure $4 \mathrm{~b}$ ). Thus, $1 \mathrm{M}$ acetate buffer was selected as the supporting electrolyte for the quantitative determination of TX from pharmaceutical dosage forms.

Scan rate studies were performed to understand the electrochemical process for TX at the surface of the MWCNT-
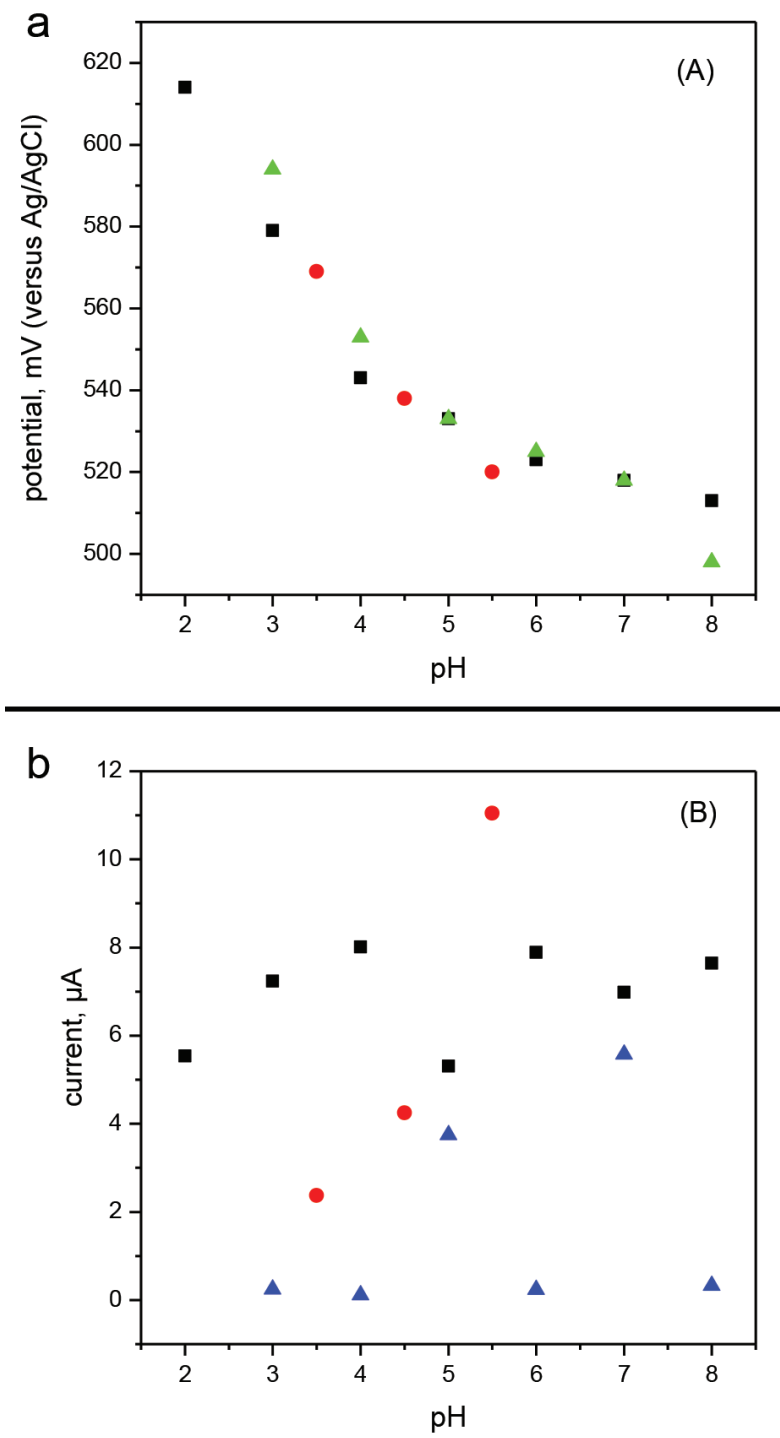

Figure 4. Plots of peak potential $\left(E_{\mathrm{p}}\right)$, versus $\mathrm{pH}$ a) and peak current $(/ \mathrm{p})$, versus $\mathrm{pH}$ b) from differential pulse voltammograms of $1.0 \times 10^{-5} \mathrm{M}$ TX with MWCNT-modified GCE. Squares indicate $0.1 \mathrm{M}$ phosphate buffer solution, triangles $0.04 \mathrm{M}$ Britton-Robinson buffer solution, and circles $1 \mathrm{M}$ acetate buffer solution

TX: Tenoxicam, MWCNT: Multiwalled carbon nanotube, GCE: Glassy carbon electrode modified GCE. The electrochemical behavior of $8 \times 10^{-5} \mathrm{M}$ TX in $1 \mathrm{M}$ acetate buffer at $\mathrm{pH} 5.5$ was investigated at different scan rates ranging from 5 to $200 \mathrm{mV} \mathrm{s}^{-1}$ by $\mathrm{CV}$. The peak potential of TX solution was shifted in the anodic direction when the scan rate was increased (Figure 5). A plot of peak current versus the scan rate showed a straight line with a slope of 0.0118 (equation 1). This indicated that the electrochemical reaction is checked by the diffusion of the electroactive species to the MWCNT-modified GCE surface. ${ }^{26,27}$ Related equations are noted below:

$I_{\mathrm{p}}=0.0118 v+0.15 ; \mathrm{r}=0.997(\mathrm{n}=8)$ (Equation 1)

It was also observed that the anodic peak current of TX shifted to a higher positive value when the scan rate was increased. This shows the irreversibility of the oxidation reaction of TX on the MWCNT-modified GCE. ${ }^{28}$

\section{Calibration curve and method validation}

Quantitative analysis of TX for validation studies was performed using DPV and SWV. The calibration curves for DPV and SWV were drawn by plotting the peak current versus the TX concentration. TX responses were linear between the ranges of $2 \times 10^{-7}$ and $1 \times 10^{-5} \mathrm{M}$ for DPV and $8 \times 10^{-9}$ and $8 \times 10^{-6} \mathrm{M}$ for SWV. Equations obtained from the calibration data were as follows:

$I_{p}(\mu \mathrm{A})=52349 \mu \mathrm{M}-0.0209 ; \mathrm{r}=0.997(n=10)$ for DPV (Equation 2) $I_{p}(\mu A)=25472 \mu \mathrm{M}+0.0039 ; r=0.997(n=14)$ for SWV (Equation 3)

$\mathrm{DP}$ and SW voltammograms for various concentrations of TX are shown in Figures 6a and 6b, respectively.

Limit of detection (LOD) and limit of quantification values were calculated according to $3 \mathrm{~s} / \mathrm{m}$ and $10 \mathrm{~s} / \mathrm{m}$, respectively (s is the standard deviation of the peak currents obtained from three sequential measurements and $\mathrm{m}$ is the slope of the related calibration graph). ${ }^{29-32}$ The characteristics of the calibration curve results for DPV and SWV are shown in Table 1.

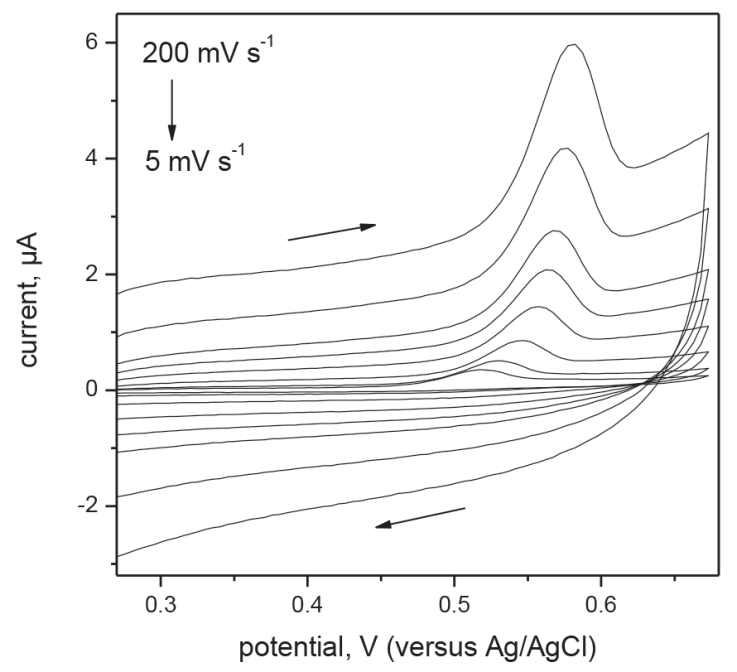

Figure 5. Cyclic voltammograms of $8.0 \times 10^{-5} \mathrm{M}$ of $\mathrm{TX}$ in $1 \mathrm{M}$ acetate buffer solution at pH 5.5 at scan rates of $5,10,25,50,75,100,150$, and $200 \mathrm{mV} \mathrm{s}^{-1}$ with MWCNT-modified GCE

TX: Tenoxicam, MWCNT: Multiwalled carbon nanotube, GCE: Glassy carbon electrode 
We determined the precision of the improved methods by repeatability and reproducibility studies. For the experiments $6 \times 10^{-6} \mathrm{M}$ TX solution in $1 \mathrm{M}$ acetate buffer at $\mathrm{pH} 5.5$ was used. To calculate relative standard deviation (RSD \%) values for DPV and SWV, five measurements were taken from different
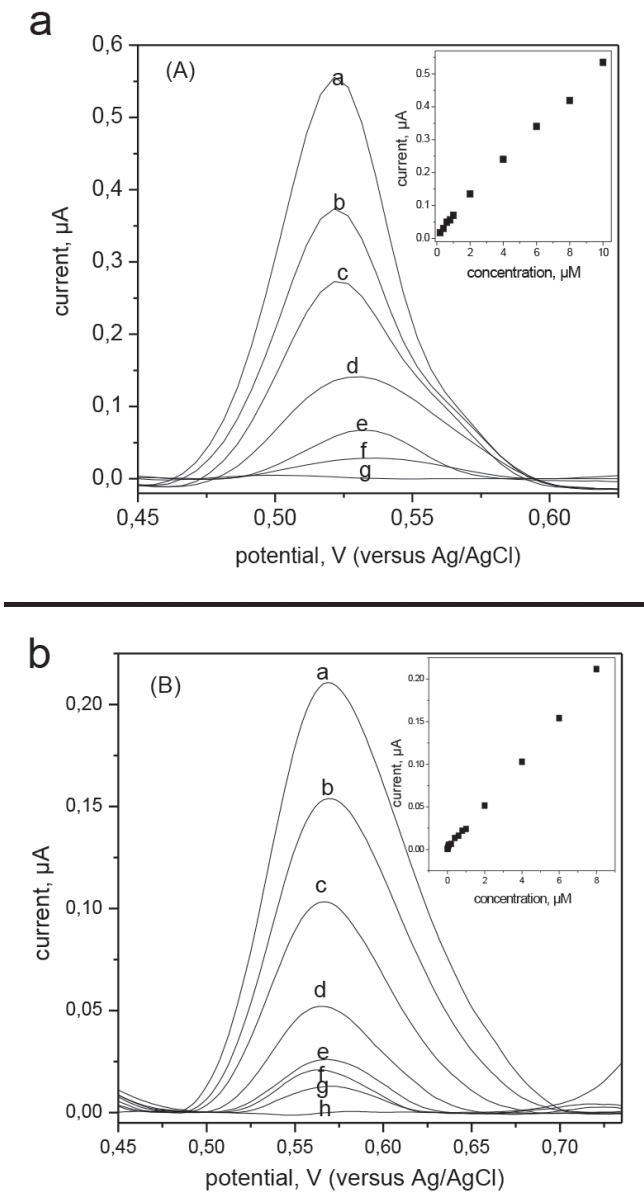

Figure 6. (a) Differential pulse voltammograms a) $1 \times 10^{-5} \mathrm{M}$, b) $6 \times 10^{-6} \mathrm{M}, \mathrm{c}$ ) $4 \times 10^{-6} \mathrm{M}$, d) $2 \times 10^{-6} \mathrm{M}$, e) $1 \times 10^{-6} \mathrm{M}$, f) $4 \times 10^{-7} \mathrm{M}$ TX in $1 \mathrm{M}$ acetate buffer solution at $\mathrm{pH} 5.5, \mathrm{~g}) 1 \mathrm{M}$ acetate buffer solution at $\mathrm{pH} 5.5$ with MWCNT-modified GCE; (b) Square wave voltammograms a) $8 \times 10^{-6} \mathrm{M}$, b) $6 \times 10^{-6} \mathrm{M}$, c) $4 \times 10^{-6}$ $\mathrm{M}$, d) $2 \times 10^{-6} \mathrm{M}$, e) $1 \times 10^{-6} \mathrm{M}$, f) $\left.6 \times 10^{-7} \mathrm{M}, \mathrm{g}\right) 4 \times 10^{-7} \mathrm{M}$ TX in $1 \mathrm{M}$ acetate buffer solution at $\mathrm{pH} 5.5$, h) $1 \mathrm{M}$ acetate buffer solution at $\mathrm{pH} 5.5$ with MWCNTmodified GCE

TX: Tenoxicam, MWCNT: Multiwalled carbon nanotube, GCE: Glassy carbon electrode solutions with the same TX concentrations in a day for repeatability and on different days of a week for reproducibility. These results (Table 1) demonstrated that the developed methods with the MWCNT-modified GCE were good in terms of precision, accuracy, repeatability, and reproducibility.

Stability studies of the MWCNT-modified GCE were performed as a function of time. For the purpose of the peak current $4 \times 10^{-5}$ $\mathrm{M}$ TX was examined with DPV for $1 \mathrm{M}$ acetate buffer solution at $\mathrm{pH} 5.5$ on the same MWCNT-modified GCE stored at room temperature 2 months. After 4 and 8 weeks, the modified electrode kept $99.65 \%$ and $98.41 \%$ of the peak current of TX respectively. After 2 weeks the peak current value kept only

\begin{tabular}{|c|c|c|}
\hline & \multicolumn{2}{|c|}{ MWCNT-modified GCE } \\
\hline & DPV & SWV \\
\hline Peak potential (V) & 0.520 & 0.570 \\
\hline Linearity range $(\mathrm{M})$ & $2.0 \times 10^{-7}-1.0 \times 10^{-5}$ & $8.0 \times 10^{-9}-8.0 \times 10^{-6}$ \\
\hline Slope $\left(\mu \mathrm{A} \mu \mathrm{M}^{-1}\right)$ & 52349 & 25472 \\
\hline Intercept $(\mu \mathrm{A})$ & -0.0209 & +0.0039 \\
\hline Correlation coefficient & 0.997 & 0.997 \\
\hline Limit of detection (M) & $1.43 \times 10^{-9}$ & $9.97 \times 10^{-10}$ \\
\hline Limit of quantification (M) & $4.33 \times 10^{-9}$ & $3.02 \times 10^{-9}$ \\
\hline $\begin{array}{l}\text { Repeatability of peak } \\
\text { current (Relative standard } \\
\text { deviation \%)* }\end{array}$ & 0.675 & 0.411 \\
\hline $\begin{array}{l}\text { Repeatability of peak } \\
\text { potential (Relative } \\
\text { standard deviation \%)* }\end{array}$ & 0.044 & 0.319 \\
\hline $\begin{array}{l}\text { Reproducibility of peak } \\
\text { current (Relative standard } \\
\text { deviation \%)* }\end{array}$ & 0.704 & 0.896 \\
\hline
\end{tabular}

\begin{tabular}{lll}
\hline $\begin{array}{l}\text { Reproducibility of peak } \\
\text { potential (Relative }\end{array}$ & 0.961 & 0.538 \\
standard deviation \%)* & \\
\hline
\end{tabular}

TX: Tenoxicam, DPV: Differential pulse voltammetry, SWV: Square wave voltammetry, MWCNT: Multiwalled carbon nanotube, GCE: Glassy carbon electrode,

*Obtained from five experiments

\section{Table 2. Compared parameters obtained using different electrodes for the determination of TX}

\begin{tabular}{|c|c|c|c|c|}
\hline Electrode & Method & Linear range $(\mathrm{M})$ & Limit of detection $(\mathrm{M})$ & References \\
\hline Static mercury drop electrode & Differential pulse polarography & $7.41 \times 10^{-8}-5.90 \times 10^{-5}$ & $7.41 \times 10^{-8}$ & 18 \\
\hline Static mercury drop electrode & $\begin{array}{l}\text { Square wave adsorptive stripping } \\
\text { voltammetry }\end{array}$ & $8.0 \times 10^{-10}-1.0 \times 10^{-5}$ & $1 \times 10^{-10}$ & 19 \\
\hline Hanging mercury drop electrode & Differential pulse polarography & $1.24 \times 10^{-6}-9.79 \times 10^{-6}$ & - & 20 \\
\hline MWCNT-modified & Differential pulse voltammetry & $2.0 \times 10^{-7}-1.0 \times 10^{-5}$ & $1.43 \times 10^{-9}$ & This work \\
\hline
\end{tabular}

TX: Tenoxicam, MWCNT: Multiwalled carbon nanotube, GCE: Glassy carbon electrode 
95.12\%. Consequently, the MWCNT-modified GCE demonstrated long-term stability.

In the literature, electroanalytical determination of TX has been achieved with various electrodes. In Table 2 , the results obtained in the present study and from other voltammetric studies in the literature were compared in terms of electrode, linearity range, and LOD. El-Maali et al.'s ${ }^{19}$ study demonstrated a wider linearity range and a lower LOD value. However, the use of a mercury electrode is a disadvantage because of the highly toxic nature of the mercury. In the present study, the MWCNTmodified GCE provided a good linear range and detection limit with SWV and the MWCNT-modified GCE. Additionally, it has some advantages such as easy preparation, user friendliness, and long-term stability. As a result, the MWCNT-modified GCE can be used more safely and sensitively in the electroanalytical determination of TX.

\section{Tablet analysis}

DPV and SWV methods developed using the MWCNT-modified GCE were applied for the determination of TX in pharmaceutical dosage forms (Tilcotil ${ }^{\circledR}$ tablets). Each tablet in pharmaceutical dosage form contains $20 \mathrm{mg}$ of TX. The DPV and SWV methods were applied in direct determination of TX in pharmaceutical dosage form without pretreatment such as extraction or evaporation steps. Furthermore, recovery studies with the proposed methods and modified electrode were also carried out via adding known amounts of pure TX to pharmaceutical form. Five repetitive experiments were done using the related calibration curve, which is a straight line, and the obtained results are demonstrated in Table 3. As shown in Table 3, the results were satisfactory and indicated the validity of the methods and modified electrode for the determination of TX in pharmaceutical form.

Table 3. The results for the determination of TX from tablet dosage forms and recovery experiments in $1 \mathrm{M}$ acetate buffer at $\mathrm{pH} 5.5$ by DPV and SWV on MWCNT-modified GCE

\begin{tabular}{lll} 
& \multicolumn{2}{l}{ Tablet (mg) } \\
\cline { 2 - 3 } & $\begin{array}{l}\text { Differential pulse } \\
\text { voltammetry }\end{array}$ & $\begin{array}{l}\text { Square wave } \\
\text { voltammetry }\end{array}$ \\
\hline Labeled claim (mg) & 20 & 20 \\
\hline Amount found (mg) & 19.871 & 20.260 \\
\hline Relative standard deviation \% & 0.714 & 0.638 \\
\hline Bias \% & 0.645 & -1.3 \\
\hline Added (mg) & 20.00 & 20.00 \\
\hline Found (mg)* & 20.035 & 20.018 \\
\hline Average recovered (\%) & 100.865 & 100.307 \\
\hline $\begin{array}{l}\text { Relative standard deviation \% } \\
\text { of recovery }\end{array}$ & 0.799 & 0.704 \\
\hline Bias \% & & \\
\hline
\end{tabular}

TX: Tenoxicam, DPV: Differential pulse voltammetry, SWV: Square wave voltammetry, MWCNT: Multiwalled carbon nanotube, GCE: Glassy carbon electrode

\section{CONCLUSIONS}

In the present study, a MWCNT-modified GCE was prepared for sensitive determination of TX. The fully validated DPV and SWV results demonstrated high sensitivity and reproducibility and repetitively via the developed sensor. The developed sensor was used for the determination of TX in pharmaceutical form by DPV and SWV without any pretreatment. The results were recovered in high percentages. In addition, the prepared electrode in this study is very useful in voltammetric studies of TX due to its high accuracy, sensitivity, stability, and repeatability, as well as its practical preparation. The sensor and method for determining accurate TX concentrations can be used in biological samples for pharmacokinetic studies and quality control laboratories.

Conflicts of Interest: No conflict of interest was declared by the authors.

\section{REFERENCES}

1. Guzmán-Hernández DS, Ramírez-Silva MT, Palomar-Pardavé M, Corona-Avendano S, Galano A, Rojas-Hernández A, Romero-Romo M. Electrochemical characterization of tenoxicam using a bare carbon paste electrode under stagnant and forced convection conditions. Electrochimica Acta. 2012;59:150-155.

2. Múnera-Jaramillo Ml, Botero-Garcés S. Determination of tenoxicam in plasma by high-performance liquid chromatography. J Chromatogr Biomed Sci Appl. 1993;616:349-352.

3. Semreen MH, Aboul-Enein HY. LC-UV method development and validation for the nonsteroidal anti-inflammatory agent tenoxicam. J Liq Chromatogr RT. 2010;33:720-729.

4. Sora I, Galaon T, Udrescu S, Negru J, David V, Medvedovici A. Fast RPLC-UV method on short sub-two micron particles packed column for the assay of tenoxicam in plasma samples. J Pharm Biomed Anal. 2007; 43:1437-1443.

5. Mason JL, Hobbs GJ. Simple method for the analysis of tenoxicam in human plasma using high-performance liquid chromatography. J Chromatogr B Biomed Appl. 1995;665:410-415.

6. Sultan M, Stecher G, Stöggl WM, Bakry R, Zaborski P, Huck CW, El Kousy NM, Bonn GK. Sample pretreatment and determination of non-steroidal anti-inflammatory drugs (NSAIDs) in pharmaceutical formulations and biological samples (blood, plasma, erythrocytes) by HPLC-UV-MS and micro-HPLC. Curr Med Chem. 2005;12:573-588.

7. Ji HY, Lee HW, Kim YH, Jeong DW, Lee HS. Simultaneous determination of piroxicam, meloxicam and tenoxicam in human plasma by liquid chromatography with tandem mass spectrometry. J Chromatogr B Analyt Technol Biomed Life Sci. 2005;826:214-219.

8. Taha EA, Salama NN, Fattah Lel-S. Stability-indicating chromatographic methods for the determination of some oxicams. J AOAC Int. 2004:87:366-373.

9. Al-Momani IF. Indirect flow-injection spectrophotometric determination of meloxicam, tenoxicam and piroxicam in pharmaceutical formulations. Anal Sci. 2006;22:1611-1614.

10. Garcóa MS, Sónchez-Pedreo C, Albero MI, Gimenez MJ. Flow-injection spectrophotometric methods for the determination of tenoxicam. J Pharm Biomed Anal. 1999;21:731-738. 
11. Al-Tamrah SA. Flow injection spectrophotometric determination of tenoxicam. Anal Chim Acta. 1998;375:277-283.

12. El-Ries MA, Mohamed G, Khalil S, El-Shall M. Spectrophotometric and potentiometric determination of piroxicam and tenoxicam in pharmaceutical preparations. Chem Pharm Bull. 2003;51:6-10.

13. Amin AS. Spectrophotometric determination of piroxicam and tenoxicam in pharmaceutical formulations using alizarin. J Pharm Biomed Anal 2002;29:729-736.

14. Barary MH, Abdel-Hay MH, Sabry SM, Belal TS. Spectrofluorimetric determination of 2-aminopyridine as a potential impurity in piroxicam and tenoxicam within the pharmacopoeial limit. J Pharm Biomed Anal. 2004:34:221-226.

15. El Walily AFM, Blaih SM, Barary MH, El Sayed MA, Abdine HH, El Kersh AM. Simultaneous determination of tenoxicam and 2-aminopyridine using derivative spectrophotometry and high-performance liquid chromatography. J Pharm Biomed Anal. 1997;15:1923-1928.

16. Arcos MJ, Alonso M, Ortiz MC. Genetic-algorithm-based potential selection in multivariant voltammetric determination of indomethacin and acemethacin by partial least squares. Electrochimica Acta. 1988;43:479485.

17. Nikolic K, Bogavac M, Arsenijevik L. Coulometric determination of some antiinflammatory compounds. Farmaco. 1993;48:1131-1136.

18. Özaltin N. Differential pulse polarographic determination of tenoxicam in pharmaceuticals and added to blood. Anal Chim Acta. 2000;406:183-189.

19. El-Maali NA, Vire JC, Patriarche GJ, Ghandour MA, Christian G. Square wave and square wave adsorptive stripping comparison of the antiinflammatory drugs piroxicam and tenoxicam. Analytical Sciences. 1990;6:245-250.

20. Reguera C, Ortiz MC, Arcos MJ. Differential pulse voltammetric simultaneous determination of four anti-inflammatory drugs by using soft modelling. Electroanalysis. 2002;14:1699-1706.

21. Ağın F, Serdaroğlu V. Voltammetric determination of nimesulide using multiwalled carbon nanotubes modified carbon paste electrode. Turk J Pharm Sci. 2016;13:335-341.

22. Bozal-Palabiyik B, Uslu B. Comparative study for voltammetric investigation and trace determination of pramipexole at bare and carbon nanotube-modif ied glassy carbon electrodes. Ionics. 2016;22:25192528.

23. Patil RH, Hegde RN, Nandibewoor ST. Electro-oxidation and determination of antihistamine drug, cetirizine dihydrochloride at glassy carbon electrode modified with multi-walled carbon nanotubes. Colloids Surf B Biointerfaces. 2011;83:133-138.

24. Wang J. Carbon-nanotube based electrochemical biosensors: a review. Electroanalysis. 2005;17:7-14.

25. Rodríguez-Barrientos D, Rojas-Hernández A, Gutiérrez A, MoyaHernández R, Gómez-Balderas R, Ramírez-Silva MT. Determination of pKa values of tenoxicam from $1 \mathrm{H}$ NMR chemical shifts and of oxicams from electrophoretic mobilities (CZE) with the aid of programs SQUAD and HYPNMR. Talanta. 2009;80:754-762.

26. Laviron E, Roullier L, Degrand C. A multilayer model for the study of space distributed redox modified electrodes: Part II. Theory and application of linear potential sweep voltammetry for a simple reaction. Journal of Electroanalytical Chemistry. 1980;112:11-23.

27. Doğan-Topal B, Uslu B, Ozkan SA. Investigation of Electrochemical Behavior of Lipid Lowering Agent Atorvastatin Calcium in Aqueous Media and its Determination from Pharmaceutical Dosage Forms and Biological Fluids Using Boron-Doped Diamond and Glassy Carbon Electrodes. Comb Chem High Throughput Screen. 2007;10:571-582.

28. Amare M, Aklog S. Electrochemical determination of caffeine content in ethiopian coffee samples using lignin modified glassy carbon electrode. J Anal Methods Chem. 2017;2017:3979068.

29. Riley CM, Rosanske TM, Development and Validation of Analytical Methods (1 st ed). New York; Elsevier; 1996:1-349.

30. Swartz ME, Krull SI. Analytical Method Development and Validation, New York; Marcel Dekker; 1997:17-34.

31. Ermer J, Miller HMcB. Method Validation in Pharmaceutical Analysis. Weinheim; Wiley-VCH; 2005:21-120.

32. Gumustas M, Ozkan SA. The role of and the place of method validation in drug analysis using electroanalytical techniques. The Open Analytical Chemistry Journal. 2011;5:1-21. 